\title{
An Empirical Study of Social Marketing Programme on HIVIAIDS
}

* Dr. Tika Ram

** Dr. Dalbir Singh

Effulgence

Vol. 11 No. 1

January - June, 2013

Rukmini Devi Institute of Advanced Studies

E-mail : effulgence@rdias.ac.in, Website : www.rdias.ac.in http:/ / effulgence.rdias.ac.in/user/default.aspX

https://dx.doi.org/10.33601/effulgence.rdias/v11/i1/2013/01-09

\begin{abstract}
A bstract
Social marketing approach can be used to influence the target audience to changetheir behaviour to wards improving health and quality of life. Descri ptive research design has been used in thestudy with the purpose of describing awareness level and attitude of students regarding social marketing issues on HIV / A IDS programme. A sample of 245 students has been collected from Gurgoan District of Haryana. By employing principal component analysis 10 factors have been extracted explaining 66.918 per cent of variance out of 30 variables of the study. The study shows that women lack awarenessregarding modesand prevention of HIV / AIDS which can bedueto status of women in the society in reference to their education, exposure to media and role in the matters of sex. With increase in ageand education, awareness and knowledgeabout different aspectsof H IV / A I D Sal so increasesasobserved in thestudy.
\end{abstract}

Key W ords: HIV / AIDS, A ttitude, Social Marketing.

\section{INTRODUCTION}

$\mathrm{T}$ he Human immunodeficiency virus (HIV), is the virus that causes acquired immune deficiency syndrome (AIDS), has spread worldwide and infecting to date (June 2002) more than 14000 individuals every day. Since the discovery of virus in 1981, more than 20 million people have died of AIDS (UNAIDS, 2004). Public $\mathrm{H}$ ealth Policy has proved to be an effective tool for containing the HIV/AIDS epidemic. The $\mathrm{N}$ ational AIDS Control Programme (N ACP) launched in 1987 was responsible for health education and care as well as screening and surveillance. A ccording to current policy, all sections of society are targeted rather than groups with increased risk of infection only. The NACP acknowledges the need to promote greater awareness amongst the public as a whole, ensures a policy of nondiscrimination towards individuals infected with H IV or AIDS, and focuses more resources upon HIV prevention activities, awareness generation, condom promotion, prevention of parent to child transmission, increasing ICTC (Integrated Counselling and Testing Centre) services, promotion of voluntary blood donation and access to safe blood.

In India people in the age group of $15-29$ years comprise almost 25 per cent of the country's population and they account for 31 per cent of AIDS burden. Based on the surveillance data (India Together, 2007) of $\mathrm{N}$ ational A IDS C ontrol O rganisation (N ACO), there are around 5.206 million HIV infected people in India; making it the second country in the world in absolute numbers after South Africa. Prevention is the mainstay of the strategic response to HIV/AIDS in India as 99 per cent population of the country is uninfected. The HIV prevalence pattern in the remaining one per cent population largely determines the need of prevention and control strategy for the epidemic in the country.

A ccording to $\mathrm{NACO}$, an estimated 2.31 million people in India were living with HIV/AIDS in the year 2007 (88.7\% adults in $15-49$ years, $7.5 \%$ aged 50 and above and $3.5 \%$ children below 15 years). The prevalence rate of H IV / AIDS in the country is $0.34 \%$. W omen account for $39 \%$ of HIV burden in the country ( $\mathrm{N}$ ational Policy on 
H IV / A IDS and the World of Work Ministry of Labour and Employment Government of India). N ew HIV infections has declined by more than $50 \%$ over the past decade from 2.7 lakh in 2000 to 1.2 lakh in 2009 and the adult HIV prevalence at national level has continued its steady decline from $0.41 \%$ in 2000 through $0.36 \%$ in 2006 to $0.31 \%$ in 2009 (N A C O State Fact Sheets, M arch 2012).

There is hardly any country in the world, which is not affected by the menace of HIV/AIDS epidemic. Everyone has same chance of being infected with HIV. HIV prevention needs to reach people who are at risk of HIV infection and those who are already infected. Bush and Davies (1989) have argued that in the absence of chemical cure or vaccine, the only tool available to fight is dissemination of public information and education on HIV/AIDS. The joint UN programme on HIV/AIDS (UNAIDS), World Bank and other national governments and agencies are working collectively to contain H IV/AIDS prevention and management. Social marketing is one of the approaches that tries to bring voluntary change in the current patterns and promotes improved alternate behaviour to help individuals and society in getting rid of social problems. Social marketing approach can be used to influence the target audience to change their behaviour for improving health and quality of life.

\section{HIV/AIDS STATUS IN HARYANA}

AIDS is assuming alarming proportions in $\mathrm{H}$ aryana as every district is having some H IV positive people. The number of cases per thousand was 0.3 in 1986, has shown a steep increase from 2.8 in 1996 to 8.1 in 1997. The situation is much more threatening than what the official figures reflects. According to medical practitioners, the blood samples which are screened by hundreds of private laboratories throughout the state do not conduct HIV tests and a large number of cases go unnoticed and unreported. The Haryana government has established 22 Integrated Counselling and Testing Centres (ICTC) at Government General Hospitals and Community $\mathrm{H}$ ealth $\mathrm{C}$ entres in the state in compliance to NACP and with the aim to spread awareness about AIDS in the susceptible community. According to the UNAIDS / WHO 2006 report on the global AIDS epidemic, 486 fresh cases of HIV/AIDS have been reported in $\mathrm{H}$ aryana last year, which accounts 13 per cent of the country's total figures.

\section{REVIEW OF LITERATURE}

To gain insight and understanding the background, following literature review has been carried out.

Condom social marketing has resulted in destigmatisation or normalisation of condoms and their use in population in general and particularly those at high risk of HIV infection (UNAIDS). A Itman Dennis (1999) exhorted coordinated efforts of Governments to make international system to work more effectively in dealing with the HIV/AIDS epidemic. A skew Ian et al (2003) reviewed the contribution of SRH (Sexual and Reproductive $\mathrm{H}$ ealth) Programmes to HIV/AIDS prevention and treatment and have shown that sexual and reproductive health programmes can make important contribution to HIV prevention and treatment and that STI (Sexually T ransmitted Infections) control is important both for sexual and reproductive health and HIV/AIDS control. Benatan Solomon R. (2001) suggested narrowing down the disparities of global economic apartheid in dealing with HIV / AIDS.

Blair Jill F. et al (1994) emphasized that the professionals and policy makers, in their efforts to stop the spread of HIV/AIDS should stress on dispelling the myths and clarifying truths about HIV transmission and the best means of prevention. Bollinger Lori et. al. (2004) identified large number of gaps to be filled by further research and evaluation. They have highlighted that if abstinence program for youths are core part of US policy, better research would be useful and national and international organizations are urging companies to implement programs at workplace. Deodhar N . S. (2003) emphasized the need to switch from IEC (Information, Education and Communication) to BCC (Behavior Change Communication). Based on review, it is observed that limited research has been carried out on social marketing of HIV/AIDS programme targeted for youth population. H earst $\mathrm{N}$ orman et. al. (2004) analyzed the impact of use of condoms in preventing HIV/AIDS and found that though the condoms have effectiveness of about 90 percent in preventing H IV but the impact of 
condoms is limited because of inconsistent use, less use among those at highest risk and negative interactions with other prevention strategies. They have recommended that there should be more promotion of condoms for those at highest risk and integration of this approach with other strategies of prevention.

Kelly Jeffrey A. (1995) identified psychological, social, and situational factors that influ-ence HIV sexual risktaking behavior, as well as the successful adoption of risk reduction behavior change. $\mathrm{O} n$ a larger scale, accelerated trials of community-level norm and behavior change inter-ventions are needed. The main challenges in HIV primary prevention is adapting behavior change models and procedures to sexual and drug use behaviors. Markku Loytonen (1991) has suggested that diffusion models based on variables representing behavior of a whole society should be created. The ABC approaches of HIV prevention are controversial in the sense that they $(A B C)$ connote different meaning to different people across various countries like whether $A$ stands for (A bstain or A bstience for youth, including the delay of sexual debut and abstinence until marriage or A bstinence or delaying first sex). Similarly meaning of $B$ is ambiguous. Most controversial is the C (Condomise or Correct and consistent use of condoms for those who practice high-risk behaviours or Correct and consistent use of condoms for sexually active young people, couples in which one partner is HIV-positive, sex workers and their clients, and anyone engaging in sexual activity with partners who may have been at risk of H IV exposure).

The goal of HIV prevention is to help people to learn how to eliminate or reduce risk of becoming infected with HIV or of transmitting HIV to others. HIV prevention takes place at two levels- The Primary and Secondary Prevention (Bai Pushpa, accessed from: www.cws-adu.org/ Pushpa\%20bai.pdf). The N GO s can adopt number of strategies such as peer-group approach, capacity building of the project personnel, condom promotion strategies, accessibility of IEC (Information, Education and Communication) materials, STD diagnosis \& treatment counseling, outreach work strategies and intervention at the community levels (Veeramatha, accessed from: www.isec.ac.in/ prcabs17.pdf). U.S. Centres for Disease Control and
Prevention (1993) strongly advocated consistent use of condoms in sexual activities for checking transmission of HIV. William ARP III (2004) found that the HIV prevention programs should focus on answering queries regarding HIV transmission rather than laying focus on changing the behaviour. Based on review, it is observed that limited research has been carried out on social marketing of HIV/AIDS programme targeted on youth population.

\section{RESEARCH METHODOLOGY}

Descriptive research design has been used in the study with the purpose of describing awareness level and attitude of students regarding social marketing issues on HIV/AIDS programme.

\section{R esearch 0 bjective}

The social marketing programme on HIV/AIDS has been implemented with the objective of creating awareness on various issues of H IV / A IDS like modes of transmission, misconceptions and prevention and achieving behavioural changes in the context of HIV. The present study is a step in discerning the effectiveness of social marketing programme. The study aims at knowing awareness level of the students and finding their attitude regarding different aspects of social marketing programme on HIV/AIDS.

The study shall test the following hypotheses:

H o1: O n gender basis, there is no significant difference in the attitude regarding HIV / AIDS.

$\mathrm{H}$ 02: O $\mathrm{n}$ age basis, there is no significant difference in the attitude regarding H IV / AIDS.

H 03: O $n$ education basis, there is no significant difference in the attitude regarding HIV / AIDS.

\section{Sampling Technique}

The sample for the study has been taken by using stratified random sampling method. The students of Gurgoan district constituted the population were divided into three group viz. school (10+1 and $10+2)$, undergraduate and post graduate level. Three lists of students at school, undergraduate and post graduate level 
were prepared with the help of roll numbers and students were randomly selected from these lists.

\section{Sample D escription}

A sample of 245 students was collected from Gurgoan D istrict of $\mathrm{H}$ aryana. The sample includes 142 male and 103 female students out of which 113 belong to 14-18 years and 132 belong to 19-23 years of age group and 102, 64 and 79 were studying in school $(10+1$ and $10+2)$, undergraduate and post graduate courses respectively.

\section{D ata Collection Instrument}

Since the study is based on primary data, a questionnaire was designed and pilot tested. The questionnaire consisted of 30 statements on 5-point likert scale ranging from strongly agree to strongly disagree.

\section{A nalysis Tools}

The data has been analysed with the help of Factor A nalysis Principal Component M ethod and hypothesis testing has been carried out by applying t-test of independence for making comparison between Gender (Male/ Female), A ge (14-18/ 19-23 years) and one wayA N OVA for testing equality on the basis of Education (School/U ndergraduate/ Post Graduate). The data has been analysed with the help of SPSS 16.0. In order to facilitate comparison and interpretation on the basis of gender, age and education in terms of extracted factors, the factor scores have been normalized into 10 point scale by using the following conversion formula:

$$
Z=\frac{(\text { Fa-Fmin }) * 10}{(\text { Fmax }- \text { Fmin })}
$$

Z - Standardized factor score on a scale of 10

$\mathrm{Fa} \quad$ - A ctual value of factor score

Fmax - M aximum value of factor score

Fmin - M inimum value of factor score

\section{DATA AN ALYSIS}

By employing principal component analysis 10 factors have been extracted explaining 66.918 per cent of variance out of 30 variables of the study. The factors were rotated (orthogonal) by Varimax with Kaiser $\mathrm{N}$ ormalization and rotations converged in 19 iterations. In rotated factor matrix, loading of variables on extracted factors above .49 have been considered. The Table I summarises these 10 extracted factors.

(IN SERT TABLE 1 HERE)

\section{D ata R eliability}

The reliability of data has been ensured through reliability statistics Cronbach's A Ipha found to be .751 for the 30 variables included in the study. The KMO measure of sampling adequacy is found to be .807 and Bartlett's test of Sphericity is 2503.360 (df: 435) with a significance of 0.000 .

(IN SERT TABLE 2 HERE)

\section{Comparison on $\mathrm{G}$ ender Basis}

From Table II, it is observed that male and female have significant differences regarding 04 factors viz. Knowledge of HIV misconception, HIV prevention by promoting safe injecting behaviour and STD diagnosis, HIV prevention by promoting safe sex behaviour and HIV spread through common illness and faithfulness in sexual relationship. This shows that women lack awareness regarding modes and prevention of HIV/AIDS which can be due to status of women in the society in reference to their education, exposure to media and role in the matters of sex. Gender inequality in terms of access to media, knowledge of AIDS and condom use, social and cultural norms favouring male domination in sexual and reproductive matters place women at lower level of awareness and attitude towards HIV/AIDS in relation to men (Mitra A parna et al. 2011). N icholas R ebecca (2010) observed that though the women have gained knowledge and awareness of H IV / A IDS and intends to follow prevention advice but the interaction between poverty and gender inequality hinder protective behaviour necessary to check spread of HIV.

\section{Comparison on A ge Basis}

On the basis age (14-18 and 19-23 years), students in the 02 age groups differ significantly on 03 factors namely 
H IV prevention by promoting safe injecting behaviour and STD diagnosis, availability and cost of HIV treatment and HIV spread through common illness and faithfulness in sexual relationship (Table $\mathrm{N} \mathrm{O}$. II). As an individual grows up towards achieving adolescence, he/ she learns about H IV / A IDS and sexual matters.

(IN SERT TABLE 3 HERE)

\section{Comparison on Education basis}

The 03 group of students at school, undergraduate and post graduate level differ significantly on 02 factors named availability and cost of HIV treatment and HIV spread through common illness and faithfulness in sexual relationship (T able III). W ith increase in education level, students are exposed to different learning media and they are more aware and informed regarding HIV/AIDS. $\mathrm{N}$ orman Lisa R. et al. (2003) found that higher level of education is associated with increased level of HIV knowledge.

\section{Fit of Factor Analysis Model}

The fit of factor analysis model has been checked through reproduced correlation matrix wherein 124 $(28 \%)$ residuals have been observed with absolute value greater than .05 indicating an acceptable model fit.

\section{FINDINGS}

The gender comparison points states that females' awareness of modes and prevention of H IV / A ID S is low in comparison to males' which can be attributed to gender inequality in the society. A ge and education level directly affects the awareness and prevention knowledge of HIV/AIDS.

\section{CONCLUSION}

The gender differences portends that social marketing programme on HIV/AIDS needs a different strategy focusing on females learning and awareness of social issues, exposure to media, their roles in decision making regarding health and family welfare issues for promoting gender equality. The social marketers should promote the desired behaviour for preventing the spread of HIV infection.

\section{ACKNOWLEDGMENT}

The study is a part of M ajor Research Project sponsored by U niversity G rants Commission, $\mathrm{N}$ ew $\mathrm{D}$ elhi.

\section{REFERENCES}

1. Altman Dennis (1999), Globalization, Political Economy and HIV/AIDS - Theory and Society, Springer, Vol.28 N 0.4, pp. 559-584.

2. A skew Ian et al. (2003), The Contribution of Sexual and Reproductive $\mathrm{H}$ ealth Services to the fight against H IV / A IDS: A Review, Reproductive H ealth Matters, Vol. 11, N o.22, , pp. 51-73.

3. Bai Pushpa N. V., Strategies for preventing the occurrence of HIV/AIDS among women and children, Accessed from: www.cwsadu.org/ Pushpa\%20bai.pdf, 2009.06.23.

4. Benatan Solomon R. (2001), South Africa's transition in a globalizing world: HIV/AIDS as a Window and A Mirror, International Affairs (Royal Institute of International Affairs- 1944), Blackwell Publishing, Vol.77 N 0.2, pp. 347-375.

5. Blair Jill F. et al (1994), Public policy implications of HIV/AIDS in adolescents, the future of children, Vol. 4, N o. 3, Critical, H ealth Issues for Children and Youth (Winter 1994), pp. 73-93, Princeton University.

6. Bollinger Lori et al (2004). Where are the Gaps? The effects of HIV- Prevention Interventions on Behavioural Change, Studies in Family Planning, Vol. 35, N o. 1 ( M arch 2004), pp.27-38, Population Council.

7. Bush, A.J. and Davies, V. (1989), State Governments' Response to the AIDS crisis: An Advertising Perspective, Journal of Public Policy and $M$ arketing, $\mathrm{Vol}$. 8, pp. 53-63.

8. Deodhar N.S (2003), Review of the $\mathrm{N}$ ational H IV / A ID S control programme in India with a view in making it community oriented - more effective and sustainable. Journal of Public Health Policy, Vol. 24 N o. 2, pp. 159-180.

9. H earst N orman and Chen Sanny (2004), Condom promotion for AIDS prevention in developing world: Is it working? Studies in Family Planning, Vol. 35 N o. 1, pp.39-47.

10. India Together on the Y ounger Side of AIDS - 15 February $2007 \mathrm{htm}$. 
11. Kelly Jeffrey A. (1995), A dvances in HIV/AIDS Education and Prevention, Family Relations, $\mathrm{H}$ elping Contemporary Families, $\mathrm{N}$ ational Councils for Family Relations, Vol. 44 N 0. 4, pp. 345--352.

12. Markku Loytonen (1991), The spatial diffusion of H uman Immunodeficiency Virus Type I in Finland, 1982-1997, Taylor \& Francis, Vol. 81 N o. 1 (March 1991), pp.127-151.

13. M itra A parna and Sarkar Dipanwita (2011), Gender inequality and the spread of HIV - AIDS in India, International Journal of Social Economics, Vol. 38 N o. 6, pp. 557-572.

14. N icholas Rebecca (2010), H IV prevention for young women of $U$ ganda must now address poverty and gender in inequalities, Journal of health organisation and management, Vol. 24 N o. 5, pp. 491-497.

15. N orman Lisa R. and Carr R obert (2003), the role of HIV knowledge on HIV - related behaviours: a hierarchical analysis of adults in Trinidad, $\mathrm{H}$ ealth Education, Vol. 103 N 0. 3, pp. 145-155.
16. UNAIDS (2004), "Executive Summary: 2004, Report on the global AIDS epidemic".

17. UNAIDS, Social Marketing: An effective tool in global response to HIV/Aids, UNAIDS best practice collection, key material prepared by Population Services International (PSI), UNAIDS/ 98.26.

18. U N A IDS/ WH O A ID S epidemic updates (2005).

19. Veeramatha $\mathrm{C} \mathrm{S}$, Role of $\mathrm{NGOS}$ in prevention of HIV/AIDS in Karnataka, Accessed from: www.isec.ac.in/ prc-abs17.pdf, 2009.06.24.

20. William ARP III (2004), HIV/AIDS and nondecisions in Louisiana: A case study of prevention strategies in three black communities, Journal of Black Studies, Sage Publications Vol. 34 N o. 4, pp. 548-561.

Table 1 : Extracted factors name

\begin{tabular}{|c|c|c|c|}
\hline $\begin{array}{l}\text { Factor } \\
\text { (Eigen } \\
\text { Value) }\end{array}$ & $\begin{array}{l}\text { Factor Interpretation } \\
\text { (\% variance explained) }\end{array}$ & Loading & Variables included in Factor \\
\hline $\begin{array}{c}F 1 \\
(6.287)\end{array}$ & $\begin{array}{l}\text { Knowledge of H IV misconception } \\
\qquad(19.213)\end{array}$ & $\begin{array}{l}.827 \\
.817 \\
.813 \\
.800 \\
.800 \\
.736 \\
.711 \\
.637 \\
.598 \\
.580\end{array}$ & $\begin{array}{l}\text { HIV spread by working with people. } \\
\text { HIV spread by shaking hands. } \\
\text { HIV spread by caring H IV people } \\
\text { HIV can spread by socialising with H IV people. } \\
\text { HIV can spread by casual contact. } \\
\text { HIV spread by sharing telephone } \\
\text { HIV spread by hugging or kissing. } \\
\text { HIV spread by swimming. } \\
\text { HIV spread by sharing of utensils. } \\
\text { HIV spread by use the same toilet. }\end{array}$ \\
\hline $\begin{array}{c}F 2 \\
(2.677)\end{array}$ & $\begin{array}{l}\text { H IV prevention by promoting safe } \\
\text { injecting behaviour and ST D } \\
\text { diagnosis ( } 7.469 \text { ) }\end{array}$ & $\begin{array}{l}.842 \\
.717 \\
.627\end{array}$ & $\begin{array}{l}\text { HIV can be prevented by promoting safe } \\
\text { injecting behaviour. } \\
\text { Spread of H IV / AIDS can be prevented by } \\
\text { promoting safe blood transfusion. } \\
\text { HIV can be prevented by diagnosis (ST D ). }\end{array}$ \\
\hline $\begin{array}{c}\text { F3 } \\
(2.178)\end{array}$ & H IV Transmission modes(6.776) & $\begin{array}{l}.778 \\
.773 \\
.741\end{array}$ & $\begin{array}{l}\text { HIV spread through blood transfusion. } \\
\text { HIV spread through sexual activities. } \\
\text { H IV spread from infected pregnant mother } \\
\text { to her child. }\end{array}$ \\
\hline
\end{tabular}




\begin{tabular}{|c|c|c|c|}
\hline $\begin{array}{c}\mathrm{F} 4 \\
(1.722)\end{array}$ & $\begin{array}{l}\text { A vailability and Cost of H IV } \\
\text { treatment }(5.667)\end{array}$ & $\begin{array}{l}.844 \\
-.832\end{array}$ & $\begin{array}{l}\text { H IV treatment is easily available. } \\
\text { C ost of H IV / A ID S treatment is cheap. }\end{array}$ \\
\hline $\begin{array}{c}\mathrm{F} 5 \\
(1.471)\end{array}$ & $\begin{array}{l}\text { H IV prevention by promoting safe } \\
\text { sex behaviour }(5.412)\end{array}$ & $\begin{array}{l}.805 \\
.724\end{array}$ & $\begin{array}{l}\text { Spread of H IV / A ID S can be prevented by } \\
\text { promoting safer sex behaviour. } \\
\text { Spread of H IV / A IDS can be prevented by } \\
\text { use of condom during sexual activities. }\end{array}$ \\
\hline $\begin{array}{c}\mathrm{F} 6 \\
(1.352)\end{array}$ & $\begin{array}{c}\text { HIV spread through common } \\
\text { illness and } \\
\text { Faithfulness in sexual relationship } \\
\text { prevent H IV (5.127) }\end{array}$ & $\begin{array}{l}.642 \\
.492\end{array}$ & $\begin{array}{l}\text { H IV can spread by sneezing or coughing. } \\
\text { Spread of H IV / AIDS can be prevented by } \\
\text { promoting faithfulness in sexual } \\
\text { relationship. }\end{array}$ \\
\hline $\begin{array}{c}\text { F7 } \\
(10217)\end{array}$ & H IV spread through biting (4.607) & $\begin{array}{l}.807 \\
.527\end{array}$ & $\begin{array}{l}\text { H IV can spread by getting bitten by an } \\
\text { H IV / A IDS infected person. } \\
\text { H IV can spread by bite of mosquito that } \\
\text { has already bitten an infected person. }\end{array}$ \\
\hline $\begin{array}{c}\mathrm{F} 8 \\
(1.116)\end{array}$ & $\begin{array}{r}\text { D iscrimination against H IV and } \\
\text { Knowing H IV status (4.433) }\end{array}$ & $\begin{array}{l}.835 \\
.650\end{array}$ & $\begin{array}{l}\text { People discriminate against H IV infected } \\
\text { person. } \\
\text { People should know their H IV status by } \\
\text { testing of blood. }\end{array}$ \\
\hline $\begin{array}{c}\mathrm{F9} \\
(1.065)\end{array}$ & $\begin{array}{l}\text { Early sex and cause of AIDS } \\
\qquad(4.115)\end{array}$ & $\begin{array}{l}-.847 \\
.609\end{array}$ & $\begin{array}{l}\text { In order to check spread of H IV / AIDS } \\
\text { people should not have sex at an early age. } \\
\text { HIV leads to AIDS. }\end{array}$ \\
\hline $\begin{array}{c}\text { F } 10 \\
(1.044)\end{array}$ & $\begin{array}{c}\text { U nanswered queries and chance } \\
\text { of H IV infection (4.098) }\end{array}$ & $\begin{array}{l}.793 \\
.584\end{array}$ & $\begin{array}{l}\text { Q ueries on H IV/ AIDS remain unanswered. } \\
\text { A healthy looking person can be infected } \\
\text { with HIV. }\end{array}$ \\
\hline
\end{tabular}

Table 2 : F actor Mean Score: Comparing equality on the basis of G ender, A ge

\begin{tabular}{|c|c|c|c|c|c|c|}
\hline \multirow[b]{2}{*}{ Factor } & \multicolumn{3}{|c|}{ t- test (G ender) } & \multicolumn{3}{|c|}{ t- test (A ge) } \\
\hline & Gender & $\begin{array}{l}\text { Factor } \\
\text { Mean }\end{array}$ & $\begin{array}{c}\text { t* (Sig. } 2 \\
\text { tailed) }\end{array}$ & Age & $\begin{array}{l}\text { Factor } \\
\text { Mean }\end{array}$ & $\begin{array}{l}\text { t*(Sig. } 2 \\
\text { tailed) }\end{array}$ \\
\hline $\begin{array}{l}\text { Knowledge of H IV } \\
\text { misconception (F } 1 \text { ) }\end{array}$ & $\begin{array}{l}\text { Male } \\
\text { Female }\end{array}$ & $\begin{array}{l}8.2168 \\
7.6683 \\
\end{array}$ & $\begin{array}{c}2.915 \\
(.004) * *\end{array}$ & $\begin{array}{r}14-18 \\
19-23 \\
\end{array}$ & $\begin{array}{l}7.8502 \\
8.1026 \\
\end{array}$ & $\begin{array}{l}-1.337 \\
(.183)\end{array}$ \\
\hline $\begin{array}{l}\text { HIV prevention by } \\
\text { promoting safe injecting } \\
\text { behaviour and ST D } \\
\text { diagnosis (F2) }\end{array}$ & $\begin{array}{l}\text { Male } \\
\text { Female }\end{array}$ & $\begin{array}{l}7.2713 \\
6.8361\end{array}$ & $\begin{array}{c}2.051 \\
(.041)^{* *}\end{array}$ & $\begin{array}{l}14-18 \\
19-23\end{array}$ & $\begin{array}{l}6.8012 \\
7.3342\end{array}$ & $\begin{array}{c}-2.548 \\
(.011)^{* *}\end{array}$ \\
\hline
\end{tabular}




\begin{tabular}{|c|c|c|c|c|c|c|}
\hline $\begin{array}{l}\text { HIV T ransmission modes } \\
\text { (F3) }\end{array}$ & $\begin{array}{l}\text { Male } \\
\text { Female }\end{array}$ & $\begin{array}{l}6.6069 \\
6.9361\end{array}$ & $\begin{array}{l}-1.378 \\
(.170)\end{array}$ & $\begin{array}{l}14-18 \\
19-23\end{array}$ & $\begin{array}{l}6.6571 \\
6.8208\end{array}$ & $\begin{array}{l}-.690 \\
(.491)\end{array}$ \\
\hline $\begin{array}{l}\text { A vailability and Cost of } \\
\text { HIV treatment (F4) }\end{array}$ & $\begin{array}{l}\text { Male } \\
\text { Female }\end{array}$ & $\begin{array}{l}4.7947 \\
5.2581\end{array}$ & $\begin{array}{r}-1.485 \\
(.139)\end{array}$ & $\begin{array}{l}14-18 \\
19-23\end{array}$ & $\begin{array}{l}5.4248 \\
4.6169\end{array}$ & $\begin{array}{c}2.639 \\
(.009)^{* *}\end{array}$ \\
\hline $\begin{array}{l}\text { HIV prevention by } \\
\text { promoting safe sex } \\
\text { behaviour (F 5) }\end{array}$ & $\begin{array}{l}\text { Male } \\
\text { Female }\end{array}$ & $\begin{array}{l}7.1084 \\
6.4863\end{array}$ & $\begin{array}{c}2.835 \\
(.005)^{* *}\end{array}$ & $\begin{array}{l}14-18 \\
19-23\end{array}$ & $\begin{array}{l}6.6395 \\
7.0243\end{array}$ & $\begin{array}{l}-1.754 \\
(.081)\end{array}$ \\
\hline $\begin{array}{l}\text { HIV spread through } \\
\text { common illness and } \\
\text { Faithfulness in sexual } \\
\text { relationship prevent H IV } \\
\text { (F6) }\end{array}$ & $\begin{array}{l}\text { Male } \\
\text { Female }\end{array}$ & $\begin{array}{l}6.8206 \\
6.3374\end{array}$ & $\begin{array}{c}2.208 \\
(.028)^{* *}\end{array}$ & $\begin{array}{l}14-18 \\
19-23\end{array}$ & $\begin{array}{l}6.2119 \\
6.9646\end{array}$ & $\begin{array}{l}-3.526 \\
(.001)^{* *}\end{array}$ \\
\hline $\begin{array}{l}\text { HIV spread through biting } \\
\text { (F7) }\end{array}$ & $\begin{array}{l}\text { Male } \\
\text { Female }\end{array}$ & $\begin{array}{l}5.1922 \\
5.3042\end{array}$ & $\begin{array}{l}-.416 \\
(.678)\end{array}$ & $\begin{array}{l}14-18 \\
19-23\end{array}$ & $\begin{array}{l}5.2288 \\
5.2482\end{array}$ & $\begin{array}{l}-.073 \\
(.942)\end{array}$ \\
\hline $\begin{array}{l}\text { Discrimination against H IV } \\
\text { and Knowing H IV status } \\
\text { (F8) }\end{array}$ & $\begin{array}{l}\text { Male } \\
\text { Female }\end{array}$ & $\begin{array}{l}6.1920 \\
6.2021\end{array}$ & $\begin{array}{l}-.046 \\
(.964)\end{array}$ & $\begin{array}{l}14-18 \\
19-23\end{array}$ & $\begin{array}{l}6.2704 \\
6.1328\end{array}$ & $\begin{array}{c}.631 \\
(.529)\end{array}$ \\
\hline $\begin{array}{l}\text { Early sex and cause of } \\
\text { A IDS (F 9) }\end{array}$ & $\begin{array}{c}\text { Male } \\
\text { Female }\end{array}$ & $\begin{array}{l}5.8651 \\
5.7885\end{array}$ & $\begin{array}{c}.326 \\
(.745)\end{array}$ & $\begin{array}{l}14-18 \\
19-23\end{array}$ & $\begin{array}{l}5.6301 \\
6.0066\end{array}$ & $\begin{array}{l}-1.627 \\
(.105)\end{array}$ \\
\hline $\begin{array}{l}\text { U nanswered queries and } \\
\text { chance of H IV infection } \\
\text { (F 10) }\end{array}$ & $\begin{array}{c}\text { Male } \\
\text { Female }\end{array}$ & $\begin{array}{l}5.9471 \\
6.1337\end{array}$ & $\begin{array}{l}-.818 \\
(.414)\end{array}$ & $\begin{array}{r}14-18 \\
19-23\end{array}$ & $\begin{array}{l}6.1275 \\
5.9383\end{array}$ & $\begin{array}{c}.838 \\
(.403)\end{array}$ \\
\hline
\end{tabular}

*: t value for equal variance assumed (df: 243); ** Significant at .05. 
Table 3 : (AN O VA: C omparing equality of 3 groups on the basis of education)

\begin{tabular}{|l|c|}
\hline Factor & F (Sig.) \\
\hline K now ledge of H IV misconception (F 1) & $1.678(.189)$ \\
H IV prevention by promoting safe injecting behaviour and ST D diagnosis(F2) & $2.692(.070)$ \\
H IV Transmission modes (F 3) & $.308(.735)$ \\
A vailability and C ost of H IV treatment (F 4) & $4.743(.010)^{* *}$ \\
H IV prevention by promoting safe sex behaviour (F5) & $1.248(.289)$ \\
H IV spread through common illness and Faithfulness in sexual relationship prevent H IV (F6) & $9.280(.000)^{* *}$ \\
H IV spread through biting (F 7) & $.629(.534)$ \\
D iscrimination against H IV and Knowing H IV status (F8) & $1.610(.202)$ \\
Early sex and cause of A ID S (F9) & $2.142(.120)$ \\
U nanswered queries and chance of H IV infection (F 10) & $.871(.420)$ \\
\hline
\end{tabular}

** Significant at .05. 